\title{
In situ behavioural studies on echinoderm aggregations
}

\author{
Part I. Pseudocucumis mixta \\ G. KÖNNECKER \& B. F. KEEGAN \\ University College, Zoology Department; \\ Galway, Ireland
}

KURZFASSUNG: In-situ-Verhaltensstudien an Aggregationen von Echinodermen. Teil I.

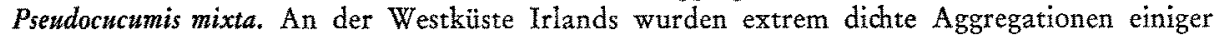
Echinodermen-Arten beobachtet. Die für die Populationsdichten einiger dieser Stachelhäuter ermittelten Werte gehören zu den höchsten, die bisher bekannt geworden sind. Die Untersuchungen konzentrieren sich auf die Lebensweise der Holothurie Pseudocucumis mixta OSTERGREN unter besonderer Berücksichtigung der Habitatpräferenz, der Art des Einbohrens in den Untergrund, der Nahrungsweise, der Defäkation und des Sinneslebens. In-situ-Studien zeigten, daß ein offensichtlich vom Tag-Nacht-Wechsel gesteuerter Freßrhythmus vorliegt.

\section{INTRODUCTION}

A study of littoral and shallow-water biotopes on the Irish west coast showed certain areas to have extremely dense populations of echinoderm species. The animals listed in Table 1 are most spectacularly aggregated.

Table 1

Density of aggregation in some echinoderm species

\begin{tabular}{|lc|}
\hline Species & Density/m $/ \mathrm{m}^{2}$ \\
\hline Antedon bifida & $>1,200$ \\
Opbiotrix fragilis & 500 \\
Ophiocomina nigra (mixed population with Antedon) & 128 \\
Amphiura filiformis & $>2,200$ \\
Paracentrotus lividus & 1,600 \\
Cucumaria elongata & 50 \\
Thyone fusus & 765 \\
Pseudocucumis mixta & $>200$ \\
\hline
\end{tabular}

Whilst the phenomenon of echinoderm aggregation is well documented (see REEsE 1966), the densities reported above appear to be amongst the highest on record for the species in question. This may reflect the use of in situ sampling techniques, particularly where infaunal animals are concerned. 
The local distribution of high density populations of the boreal sea-cucumber Pseudocucumis (= Neopentadactyla) mixta ÖSTERGREN (order Dendrochirotida) commanded the authors' special attention (Fig. 1). This included a continuous monitoring - by closed-circuit T.V. - of the holothurian's diurnal activity and feeding habits.

\section{METHODS}

Because of some difficulties encountered during this exercise, it is deemed worthwhile to describe briefly the positioning of the T.V. equipment. Operating in formidable tidal currents $(2.5$ knots), it was necessary to anchor the support craft at three

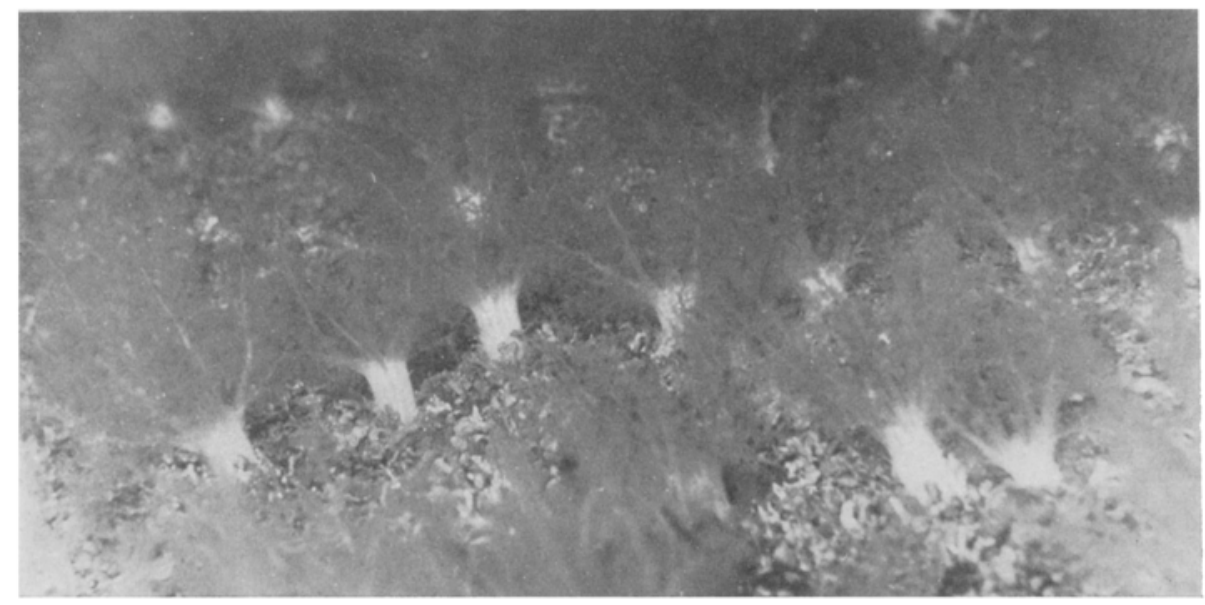

Fig. 1: Aggregated population of Psetdocucumis mixtd in maerl substrate. Maximum density: $297 / \mathrm{m}^{2}$

points. The camera/lighting cable $(100 \mathrm{~m})$ was "peg-anchored" to the sea bed some $10 \mathrm{~m}$ behind the observation site. This removed drag strain from the camera/light assembly. A direct reading current meter and paired photo cells (for ambient light measurement) were also employed.

\section{RESULTS}

\section{Habitat preference}

Throughout the study area Pseudocucumis mixta* showed a distinct preference for gravel-type substrates. Whilst it was not observed below a depth of $27 \mathrm{~m}$, MoRTENSEN (1927) reported it as occurring off the Irish west coast in depths of 32-67 m.

\footnotetext{
* Species described by Ostergren (1898, p. 135, and 1906, Pl. I, Figs 1 and 3).
} 

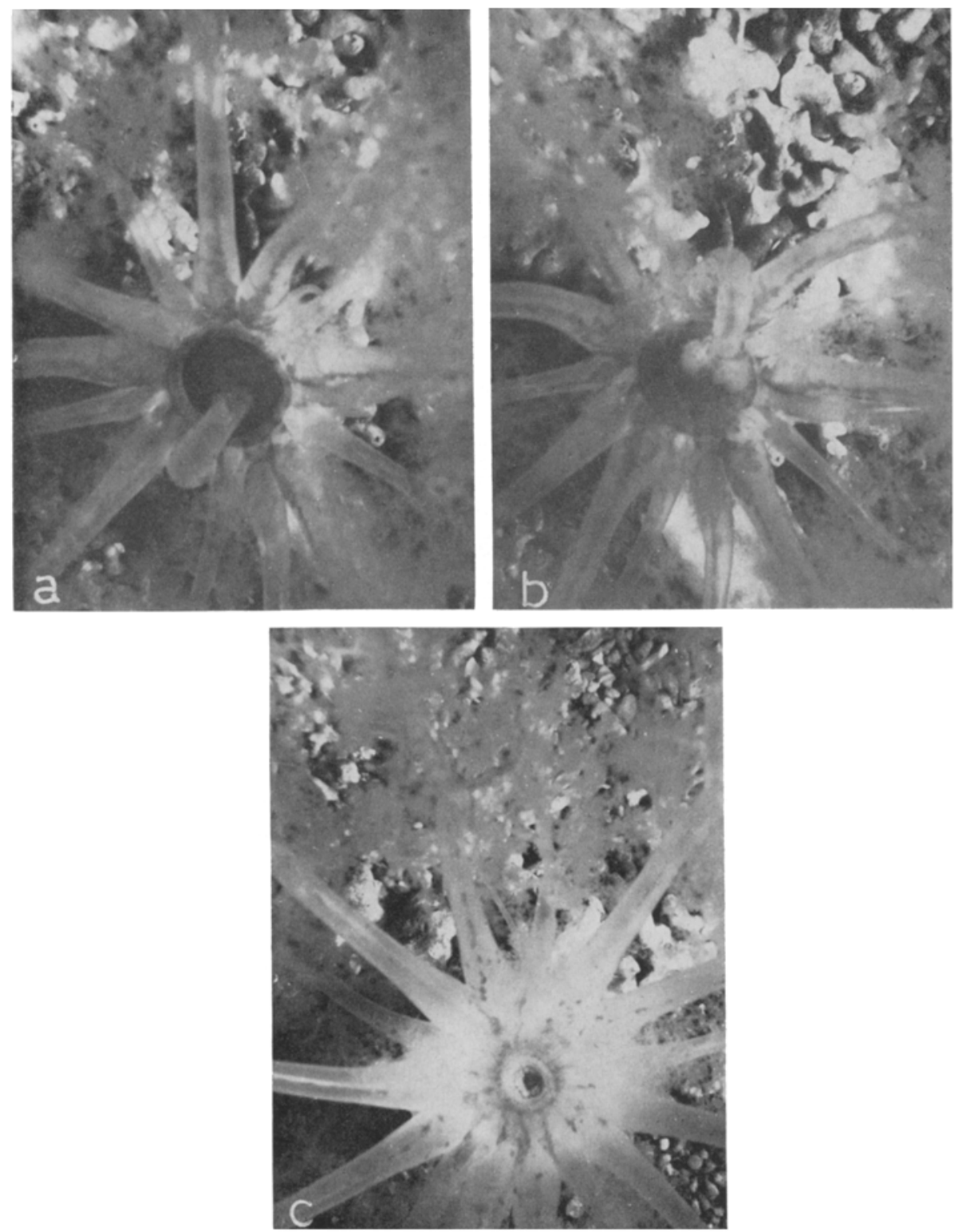

Fig. 2: Feeding sequence for Pseudocucumis mixta. a Large tentacle placed deep within the pharynx. $b$ As tentacle is withdrawn the buccal membrane contracts upon it. $c$ Buccal membrane contracted, following removal of tentacle

Highest densities were recorded for loose, mobile deposits. This type of ground would appear to be limiting to the majority of infaunal animals. A notable exception is the gastropod Balcis alba which may live in commensal association with the holothurian. 


\section{Mode of burrowing}

In the aquarium, Pseudocucumis mixta was seen to burrow by advancing the distended mid-section of the body into the substrate. The numerous irregularly arranged podia of the mid-ventral area shifted sediment particles dorsalwards. In this manner, the animal can completely bury itself in from eight to ten hours. This method of burrowing is not dissimilar to that described for Thyone briareus (PeARsE 1908). Within the sediment, the animal is typically disposed in a U-shaped form and normally burrows to a depth of from 15 to $25 \mathrm{~cm}$.

\section{Feeding}

Pseudocucumis mixta is a rheophilic suspension feeder. Food material impinges upon and adheres to 15 large mucous-coated tentacles. These are peripherally arranged about the mouth and, on full extension, are seen to be highly ramose. At intervals of from 11-13 seconds, individual tentacles partially contract, bend inwards and are placed deep within the pharynx, in random order. Occasionally more than one large tentacle may be involved. As each is progressively withdrawn the buccal membrane contracts upon it (Figs. 2a-c).

Five smaller tentacles, forming an inner circlet around the mouth, appear to play a role in the feeding process. As many as three of these structures have been observed to follow a large tentacle into the pharyngeal cavity. The writers are of the opinion that these function, with the contracted buccal membrane, in physically removing food material from the large tentacles (see FisH 1967, re feeding in Cucumaria elongata). It was noted that fragments of biogenic material placed (by a diver) over the mouth opening were pushed free of the animal by a number of the smaller tentacles working together. The large tentacles were frequently seen to assist in the same task. Unable to cope with debris above a certain size limit, the holothurians gradually retracted into the deposit.

\section{Diurnal activity}

Over the past few years, attempts to locate a population of Pseudocucumis mixta which fed during the late morning proved unsuccessful. This led the authors to believe that these holothurians exhibit a diurnal feeding rhythm. To further research this possibility, a continuous watch ( 44 hours $^{*}$ ) was maintained on a discrete area of sea bottom known to be densely populated by the animals. This was carried out at a depth of $10 \mathrm{~m}$ during a neap-tide period. The population in the immediate field of view ( $=88$ individuals) clearly exhibited a rhythmical feeding pattern.

At approximately one hour after sunrise the population started to thin out as individual sea cucumbers retracted into the deposit. In 2-3 hours, all the animals

* The experiment was prematurely terminated by adverse current conditions. 
had disappeared from view and remained so for 1-2 hours. The holothurians gradually re-emerged over a four-hour period.

\section{Defecation}

Pseudocucumis mixta defecates by marginally extending its anus free of the deposit and forcibly ejecting the faecal material. The faeces are coated with mucous and seem to be positively buoyant. This latter feature, combined with current flow, ensures that the aggregation is not self-fouling. An interesting observation in this regard is that the faeces do not adhere to the feeding tentacles of the holothurians. Defecation continues throughout the period of active feeding.

\section{Sensitivity}

Whilst the holothurians tolerate a degree of interference with the tentacles and mouth area, slight vibrations of the substrate have been observed to cause total retraction. Very strong currents and bombardment with dislodged sediment particles have the same effect. A single specimen of Psendocucumis mixta can have a tentacle spread of from $80-100 \mathrm{~cm}^{2}$. When densely aggregated this is considerably reduced (i.e., the tentacles project almost vertically) and contact between contiguous animals is minimal. $P$. mixta showed no immediate response to strong white light.

\section{DISCUSSION}

Without engaging in lengthy speculation as to the causative factors behind the extreme aggregation of Pseudocucumis mixta, it seems likely that the localised availability of a suitable substrate combined with favourable conditions of water movement and food supply would be among the more important. Subjective impressions have been that the populations in Kilkerrin Bay (Ireland) have greatly increased over the past few years. This may reflect an intensification of that mechanism whereby, as held by KNIGHT-Jones (1951), THORson (1952), etc., the larvae of certain marine animals are attracted to and induced to settle by established populations of their own species. An abetting feature may involve the topography of the general area. Pearson (1970) discusses the containment of larvae within fjordic-type systems and its effect on recruitment to the adult benthic population.

The writers hesitate to advance any factor or combination of factors as controlling the observed feeding rhythm. Yamanouchi (1956) showed that rhythmical behaviour in some holothurian species is "dependant on the cycle of external light change". CRUMP (1965) was of the same opinion in regard to the feeding habits of Holotburia tubulosa.

Whilst light also appears to be of primary importance in the case of $P$. mixta, this must be conclusively proven by further field and laboratory studies. 


\section{SUMMARY}

1. On the west coast of Ireland, a number of echinoderm species have been found to exhibit extreme aggregation. Population densities for some of these animals are amongst the highest on record.

2. Detailed studies have been carried out on aggregations of the holothurian Pseudocucumis mixta OSTERGREN. These provided information on habitat preference, mode of burrowing, method of feeding and the animal's sensitivity.

3. In situ observation established the existence of a diurnal feeding rhythm which may be primarily controlled by light.

4. The manner of defecation and the nature of the faeces would appear to rule out self-fouling by the aggregation.

Acknowledgements. We thank the various members of the Zoology Department, University College, Galway, who assisted in this work. Special recognition is due to our Director, Professor P. O'CerDrgh who suggested the project at the outset; to T. RxDer for his handling of the R.V. ONA III, and to B. TAYLOR who operated and maintained the electronic equipment. We particularly valued the participation of our colleague, A. Toulemont (Institut Océanographique, Paris).

\section{LITERATURE CITED}

CRump, R. G., 1965. The diurnal activity of holothurians. In: Symposium. Underwater Association, Malta. Ed. by J. N. Lxthgoe \& J. D. Woons. 43-45.

Fish, J. D., 1967. The biology of Cucumaria elongata (Edinodermata: Holothuroidea) J. mar. biol. Ass. U.K. 47, 129-143.

Knight-Jones, E. W., 1951. Gregariousness and some other aspects of the settling behaviour of a Spirorbis. J. mar. biol. Ass. U.K. 30, 201-222.

Mortensen, T., 1927. Handbook of the ehinoderms of the British Isles. Oxford Univ. Press, London, $471 \mathrm{pp}$.

OstergRen, H., 1898. Zur Anatomie der Dendrochiroten nebst Beschreibung neuer Arten. Zool. Anz. 21, 135.

- 1906. Einige Bemerkungen über Westeuropäische Psendocncumis- und PbyllophorousArten. Ark. Zool. 3 (18).

PeARse, A. S., 1908. Observations on the behaviour of the holothurian, Thyone briareus (Lesueur). Biol. Bull. mar. biol. Lab., Woods Hole 15, 259--288.

Pearson, T. H., 1970. The benthic ecology of Loch Linnhe and Loch Eil, a sea loch system on the west coast of Scotland. I. The physical environment and the distribution of the macrobenthic fauna. J. exp. mar. Biol. Ecol. 5, 1-34.

REESE, E. E., 1966. The complex behaviour of echinoderms. In: Physiology of Echinodermata. Ed. by R. A. Boolootinan. Wiley, New York, 157-218.

Trorson, S., 1952. Zur jetzigen Lage der marinen Bodentier-Okologie. Zool. Anz. (Suppl.) 16, 291.

Yamanovchi, T., 1956. The daily activity rhythms of the holothurians in the coral reef of the Palao Islands. Publs Seto mar, biol, Lab. 5, 347-362.

First author's address: G. KöNNECKER

University College

Zoology Department

Galway

Ireland 